\title{
Implementation of Nationally Determined Contributions under the Paris Agreement - Comparing the Approach of China and the $\mathrm{EU}^{1}$
}

\author{
By Athanasios P. Mihalakas ${ }^{*} \&$ Emilee Hyde
}

Climate change is a pressing global issue that is rapidly requiring a global response under international law. The UN Framework Convention on Climate Change was created by the UN to unite states in coordinating efforts to lower greenhouse gas emissions while continuing to develop in a more sustainable way. The Kyoto Protocol and the Paris Agreement were two succeeding efforts under the UNFCCC to decrease emissions and prepare adaptations for the effects of climate change. The Kyoto Protocol required mandatory reduction in carbon emissions by industrialised developed states, and it inevitably collapsed. The Paris Agreement required voluntary reduction of carbon emissions by all member states. In this paper, we look at the evolution of the international climate change legal regime, from the UNFCCC adaptation at Rio de Janeiro, to the failed Kyoto Protocol and the innovation of the Paris Agreement. In particular, we look at the implementation efforts by the EU and China of the Paris Agreement, as two of the major carbon emitters on the planet who are still parties to the agreement. Although both China and the EU set lofty goals in accordance with the Paris Agreement requirements, neither state's plan is adequate to deal with global warming in the long run. We argue that the greatest innovation of the Paris Agreement is in climate change related information gathering, sharing, and reporting. The rapidly deteriorating condition of the global climate makes accurate information on national carbon emission and carbon reduction efforts, essential for long-term prediction and planning. Therefore, in the fight against global warming, timely and reliable information on carbon emissions and how national governments are dealing with that have become more valuable than just complying with global targets.

Keywords: Climate Change; Global Warming; International Law; UNFCCC; Kyoto Protocol; Paris Agreement.

\section{Introduction}

The science of climate change was established long before anthropogenic sources of greenhouse gases existed. Some radiation from the sun reflects off Earth's surface instead of being absorbed, and naturally occurring molecules in the

\footnotetext{
* Global Professor of Practice in Law, University of Arizona James E. Rogers College of Law, Tucson, Arizona, USA. Corresponding Author. Email: mihalakas@arizona.edu..

IIndependent Consultant and Nazareth College Graduate, BS in Environmental Science and Sustainability. Email: ehyde3@mail.naz.edu.

${ }^{1}$ The authors thank Khrystyne H Wilson for her great help with this project.
} 
atmosphere cause some of that radiation to refract downward again. ${ }^{2}$ This 'greenhouse effect' allows the Earth to stay warm enough to harbour life. However, the number of molecules in the atmosphere changes naturally through various systems and can fluctuate enough to alter the climate. Emissions of molecules from unnaturally occurring sources have rapidly increased in the last 100 years and have become a major problem for the global climate.

Anthropogenic interference has recently caused climate change to accelerate rapidly. ${ }^{3}$ The greenhouse gas carbon dioxide $\left(\mathrm{CO}_{2}\right)$ had an atmospheric range of 260 to 300 parts per million ( $\mathrm{ppm}$ ) for ten thousand years before 1750, but from the start of the industrial era until 1999 it rose to $367 \mathrm{ppm}$, and then to $379 \mathrm{ppm}$ in $2005 .{ }^{4}$ Other greenhouse gas concentrations including methane and nitrous oxide have also increased in recent decades, as well as the presence of synthetic halocarbons which are directly linked to human activity since they were never found in the atmosphere before their production began in the 1930 's. ${ }^{5}$ Furthermore, global temperatures have increased about $1{ }^{\circ} \mathrm{C}$ since the early $20^{\text {th }}$ century, ${ }^{6}$ which is at a much greater rate than previous records indicate. ${ }^{7}$ This correlation between rise in greenhouse gas emissions and rise in global temperatures has been proven as causation by climate science over the previous few decades. ${ }^{8}$

Fossil fuels, which are burned in most forms of transportation and energy production/consumption, have been proven among other human activities to emit greenhouse gases. This is an issue because of the implications of increased climate change, including rising temperatures, loss of sea ice, subsequent sea level rise, increased severity of natural disasters, and more frequent droughts. ${ }^{9}$ Despite wellresearched and legitimate science, there has been a debate worldwide over the actual role of anthropogenic greenhouse gas emissions on global climate. ${ }^{10}$

While the science behind this research is peer-reviewed and based on over a century of reliably collected data, the problem with climate change is its global nature and the delayed manifestation of its consequences. Greenhouse gases cannot be measured precisely from every source on the planet, and it can take as long as 10 years to have an impact on global climate. ${ }^{11}$

\footnotetext{
${ }^{2}$ Taylor (1991) at 881-918.

${ }^{3}$ See Taylor (1991).

${ }^{4}$ Le Treut, Sommerville, Cunasch et al. (2007) at 100.

${ }^{5}$ Le Treut, Sommerville, Cunasch et al. (2007) at 100.

${ }^{6}$ For reference: A change in temperature of $1^{\circ} \mathrm{C}$ is equivalent to $1.8^{\circ} \mathrm{F}$.

${ }^{7}$ See ProCon.org (2020).

${ }^{8}$ Boer, McFarlane \& Lazare (1992) at 1045-77; See Bauer, Claussen, Brovkin \& Huenerbein (2003); See Stips. Macias, Coughlam et al. (2016).

${ }^{9}$ See ProCon.org (2020).

${ }^{10}$ Deniers claim that anthropogenic greenhouse gas emissions are too small to generate large changes in the atmosphere, and the planet's systems are capable of mitigating these emissions and their consequences. They argue that climate change is apparently naturally caused and the true explanation for the recent rises in global temperature, and they accuse the science behind climate change as misleading and questionable. See Dunlap (2013) at 691-698; Björnberg, Karlsson, Gilek \& Hansson (2017) at 229-241.

${ }^{11}$ Studies show maximum warming from greenhouse gases occur ten years after they were emitted into the atmosphere. See Ricke \& Caldeira (2014).
} 
Currently, scientists have concluded that consuming fossil fuels is directly linked to increased concentrations of $\mathrm{CO}_{2}$ in the atmosphere, which is the primary cause of climate change. ${ }^{12}$ While there are still many climate change deniers, national governments have adopted international legal obligations on lowering greenhouse gas emissions through the UN. The basis of these treaties stems from assessment reports by the Intergovernmental Panel on Climate Change (IPCC), and many states are working to comply.

The IPCC was established by the UN Environment Program (UNEP) and the World Meteorological Organisation (WMO) to review and assess scientific and socio-economic information regarding climate change worldwide. ${ }^{13}$ It has produced recent understandings of climate change causes and effects, and in 2014 stated that they were $95 \%$ certain that climate change is due to anthropogenic causes. ${ }^{14}$ The current goal is to reduce greenhouse gas emissions enough to stay below $1.5^{\circ} \mathrm{C}$, which research shows, would prevent many adverse effects of climate change. ${ }^{15}$ The difficulty with this goal is that it would require extreme and rapid changes to various aspects of societies worldwide. Several conventions and treaties laid out frameworks for achieving this goal, and international climate governance law is still under development.

\section{Evolution of International Climate Change Law}

Starting in the 1980's, there has been a constant increase in international legal efforts to deal with climate change. The United Nations General Assembly endorsement of the IPCC in 1988 resulted in the creation of the UN Framework Convention on Climate Change (UNFCCC), ${ }^{16}$ followed by the Kyoto Protocol in 1997, and the Paris Agreement in 2015. Both the greater understanding of climate change science and the global implications of reversing human practices of over 100 years greatly influenced the evolution of international law on climate change.

The UNFCCC was the starting point that outlined principles and goals with which to align future actions through annual discussions on the issue. Without this framework, the Kyoto Protocol and Paris Agreement would not have been created, and there would be a lack of international cooperation towards climate action. Over time, international climate change law became progressively more specific and deliberate in promoting more urgent action.

\section{UNFCCC in Rio de Janeiro}

In 1992 a conference was held in Rio de Janeiro, Brazil, that established the need for development to be sustainable; or development which meets all the needs of the present generations without compromising the needs or abilities of future

\footnotetext{
${ }^{12}$ IPCC (2014) at 47.

${ }^{13}$ See IPCC (2020).

${ }^{14}$ IPCC (2014) at 48.

${ }^{15}$ See United Nations (UN) (2019).

${ }^{16}$ See IPCC (2020).
} 
generations, so that widespread poverty and degradation of environmental resources are sufficiently lowered and technology along with social organisation are improved to allow for economic growth. ${ }^{17}$ Four major documents were produced at this conference, including the Rio Declaration on Environment and Development, the UNFCCC, the UN Convention on Biodiversity, and Agenda $21{ }^{18}$ Under the UNFCCC it was agreed that greenhouse gases needed to be stabilised at a point where human interference would not damage the global climate system. ${ }^{19}$ It was ratified by 197 parties, which gave it broad legitimacy. ${ }^{20}$

The main objective of the UNFCCC was to set targets to curb rising global temperatures due to increasing greenhouse gas emissions. ${ }^{21}$ The convention recognised that climate change was a significant issue and bound nations to protect human life, even without complete scientific certainty. ${ }^{22}$ It set a specific goal to stabilise greenhouse gas concentrations, and in order to protect food production and economic development the convention suggested that a sufficient time frame was necessary. ${ }^{23}$ Developed countries (identified as 'Annex I' countries in the UNFCCC) were expected to show leadership since they had produced the most greenhouse gas emissions historically. This higher expectation on the part of developed countries came to be known in UNFCCC lingo as "common but differentiated responsibilities" and will prove to be both necessary and controversial over time.

All signatory nations were expected to reach a goal of reducing emissions to the same level as of 1990 by the year $2000 .{ }^{24}$ A system of grants and loans was developed by the industrialised nations to provide financial and technical support for developing nations, aside from support already provided. ${ }^{25}$ Annex I countries were required to report regularly on their progress in developing relevant policies and measures, and provide annual data on greenhouse gas emissions. Developing countries had to report on their general actions towards reducing greenhouse gas emissions and were to receive funding to meet their obligations. ${ }^{26}$ These reporting requirements were to be further developed in later meetings of the parties.

The convention outlined the process for negotiating more specific international treaties that would provide precise targets and further guidelines for moving towards its goals. ${ }^{27}$ The UNFCCC targets were ambitious, but this was also the first effort at the international level to identify climate change as a global threat which needed to be addressed. The parties have met yearly at the Conference of

\footnotetext{
${ }^{17}$ WCED (1987) at 16.

${ }^{18}$ The Rio Declaration on the Environment was the basis for development of new principles and rules that would determine international environmental law; and the Agenda 21 created a comprehensive set of actions for states that came with the development of a UN Commission on Sustainable Development to review progress on the agenda. See UNCED (2020).

${ }^{19}$ Article 2 of UN Framework Convention (1992).

${ }^{20}$ See United Nations (UN) (2019).

${ }^{21}$ Article 2 of UN Framework Convention (1992).

${ }^{22}$ Article 3, Section 3 of UN Framework Convention (1992) and see UNFCCC (2019c).

${ }^{23}$ Article 2 of UN Framework Convention (1992); UNFCCC (2019c).

${ }^{24}$ Article 4, Section 2b of UN Framework Convention (1992).

${ }^{25}$ Article 11 of UN Framework Convention (1992).

${ }^{26}$ Article 12 of UN Framework Convention (1992).

${ }^{27}$ Article 17 of UN Framework Convention (1992).
} 
Parties (COP) to discuss the continued implementation of the convention and address any developments. ${ }^{28}$ At these meetings, new agreements have been adopted which created more specific targets for member states to work towards. ${ }^{29}$

\section{The Kyoto Protocol}

The first major agreement to emerge from the UNFCCC COP process was finalised at the 1997 COP3 meeting in Kyoto Japan, where member states agreed on legally binding emissions reduction targets. ${ }^{30}$ This 'Kyoto Protocol' to the UNFCCC was ratified by 192 nations. It reinforced the idea of "common but differentiated responsibilities" from the UNFCCC's original goals, which placed greater responsibility on developed countries due to their larger historical contribution of emissions. ${ }^{31}$ Annex I countries were now required to account for at least $55 \%$ of the emissions of all parties due to emissions calculated from $1990 .^{32}$ In 2001, the Marrakesh Accords adopted at COP7 created the detailed rules for the implementation of the Kyoto Protocol, and in 2005 it entered into force. ${ }^{33}$

There were two commitment periods from 2008 to 2012 and from 2013 to 2020 in which states had to agree to targets. ${ }^{34}$ The first period had a target of reducing global emission by $5.2 \%$ below 1990 levels. ${ }^{35}$ In 2012, the Doha Amendment from COP18 decided targets for the second period. ${ }^{36}$ This amendment included the new commitments for Annex I parties to reduce global emissions by $18 \%$ below 1990 levels, ${ }^{37}$ a new list of greenhouse gases to be reported on, ${ }^{38}$ and amendments to other issues found during the first period. ${ }^{39}$ The composition of parties in each period was mostly the same, with a few more parties participated in the first period than the second. ${ }^{40}$

While parties were encouraged to meet targets by adopting domestic measures, the Kyoto Protocol allowed parties to fulfil their obligations of lowering emissions by acquiring emission reduction credits through three market-based mechanisms. These flexible market-based mechanisms included the Clean Development Mechanism (CDM), the Joint Implementation (JI), and International Emissions Trading. ${ }^{41} \mathrm{CDM}$ allowed parties with commitments to establish projects in developing countries that would reduce emissions, earning them certified emission reduction (CER) credits that count toward targets. ${ }^{42}$ This allowed

\footnotetext{
${ }^{28}$ Article 7 of UN Framework Convention (1992).

${ }^{29}$ For a complete list of COP meetings, see UNFCCC (2020a).

${ }^{30}$ See UNFCCC (2019a).

${ }^{31}$ Article 10 of Kyoto Protocol (1997).

${ }^{32}$ Article 24, Section 1 of Kyoto Protocol (1997).

${ }^{33}$ See UNFCCC (2020a).

${ }^{34}$ See UNFCCC (2020a); Article 3, Section 1 of Kyoto Protocol (1997).

${ }^{35}$ Article 3, Section 1 of Kyoto Protocol (1997).

${ }^{36}$ See UNFCCC (2020a).

${ }^{37}$ Article 1, Section C of Doha Amendment to the Kyoto Protocol (2012).

${ }^{38}$ Article 1, Section B of Doha Amendment to the Kyoto Protocol (2012).

${ }^{39}$ See UNFCCC (2020a).

${ }^{40}$ Annex B of Kyoto Protocol (1997).

${ }^{41}$ See UNFCCC (2020a).

${ }^{42}$ Article 12 of Kyoto Protocol (1997).
} 
flexibility in meeting targets while stimulating sustainable development and reducing emissions. JI projects allowed parties to earn emission reduction units (ERUs) by completing projects to reduce emissions at their source or enhancing carbon capture in other countries. ${ }^{43}$ While these JI projects provided flexibility in meeting targets (same as the CDM), they promoted foreign investment and technology transfer to developing countries as well.

These emissions trading mechanisms created a new commodity and a global market for carbon emissions by allowing Annex I parties to sell their unused emissions allowance to countries which exceed their targets. ${ }^{44}$ Items that can be traded under this article are removal units (RMU) based on land use, ERUs from JI projects, and CER credits from a CDM project. Furthermore, the Kyoto Protocol facilitated the development of new technologies to adapt to the adverse effects of climate change and increase resilience. The Adaptation Fund finances these new technologies from shares of the proceeds of CDM projects, JI initiatives, and emissions trading. ${ }^{45}$

Emission reductions and records of any emission trades were to be monitored under the Kyoto Protocol. Parties must submit inventories annually, regularly submit national reports, and maintain registry systems that track transactions occurring through the three mechanisms. The UN Climate Change Secretariat monitors national actions for consistency with the requirements rules in the Kyoto Protocol, through an international transaction $\log { }^{46}$ The extensive compliance system ensured parties met their commitments or received help if needed, which was facilitated by the Compliance Committee to the Kyoto Protocol outlined at COP7. ${ }^{47}$ The system contains procedures and mechanisms in order to enforce, promote, and facilitate compliance. ${ }^{48}$ The Kyoto Protocol set targets and encouraged compliance by mandatory reports of progress and in doing so (it was expected to) set the stage for future agreements which could even more comprehensibly achieve the goals of the UNFCCC. ${ }^{49}$

Therefore, the Kyoto Protocol created a very useful and accountable system for reducing carbon emissions by industrialised developed nations that were both responsible and had the means - based on market principles. Unfortunately, what prevented Kyoto Protocol from being effective was the geopolitical reality of international law and the global community. The mandatory carbon emission targets of the Kyoto Protocol only applied to developed countries, which by then were not at all the largest carbon emitters. ${ }^{50}$ Large carbon emitters like China, India, and Russia were excluded, while the US opted not to participate. Couple that with the dubious notion of trying to enforce compliance at the international stage where sovereign nation states have to consent, and you have a well-

\footnotetext{
${ }^{43}$ Article 6 of Kyoto Protocol (1997).

${ }^{44}$ Article 6 of Kyoto Protocol (1997).

${ }^{45}$ Article 6 of Kyoto Protocol (1997).

${ }^{46}$ See UNFCCC (2020a).

${ }^{47} \mathrm{UNFCCC}(2006)$ at $93-103$.

${ }^{48}$ See UNFCCC (2002).

${ }^{49}$ Article 7 of Kyoto Protocol (1997).

${ }^{50}$ The Kyoto Protocol covered 36 countries, which accounted for only $24 \%$ of global greenhouse gas emissions in 2010. See Shishlov, Morel \& Bellassen (2016).
} 
intentioned system that was not sustainable. In particular, the mandatory carbon emissions agreed on the 2012 Doha Amendment for the second Kyoto Protocol implementation period (2013-2020) never happened, since only 138 countries adopted it, when 144 were needed in order to enter into force. ${ }^{51}$

\section{The Paris Agreement}

The global community, realizing that this perceived imbalance between developed and developing countries could undermine the entire effort, started working immediately on a new approach to combating climate change. At the UNFCCC 2015 COP21 meeting in Paris France, member states finalised and committed to a new framework. It was signed by 175 world leaders on Earth Day in 2016, and a total of 186 states ratified the agreement. ${ }^{52}$ Nations were brought together under a common cause to combat climate change and adapt to its effects, while support was also provided for developing countries to participate. ${ }^{53}$

The main goals of the Paris Agreement, according to Article 2, were: a) keep global temperature rise below $2^{\circ} \mathrm{C}$ above pre-industrial levels and to work towards keeping it below $\left.1.5^{\circ} \mathrm{C}, \mathrm{b}\right)$ increase adaptation and resilience to the adverse impacts of climate change (while promoting sustainable development and the protection of food production), c) facilitate consistent investment into 'low greenhouse gas emissions and climate resilient development. ${ }^{54}$

Implementation of the Paris Agreement goals is to be achieved through a combination of initiatives and mechanisms, which can be divided into two categories. On the one hand, there are initiatives that have to be reported to the UN Climate Change Secretariat and all the other UNFCCC parties, like Mitigation (Art. 4), Adaptation (Art. 7), Technology Transfer (Art. 10), and Capacity Building (Art 11). On the other hand, mechanism like Forests Sinks and Reservoirs (Art 5), Market Cooperative Mechanisms (Art 6), and Loss and Damage (Art 8), don't have to report by member states for the Article 13 'peer-review' process.

In particular, the Paris Agreement encourages parties to pursue national policies that progressively mitigate the rise of carbon emissions, enhance their adaptive capacity to climate change, and address loss and damage caused by extreme and slow weather events. Parties are to do that through a 'ratcheting up' process, in five-year increments, through enhanced Nationally Determined Contribution's (NDC's). In order to help with this process, parties should use forest conservation and enhancement of carbon capture methods (like carbon sinks and reservoirs), that can help offset their carbon emissions. ${ }^{55}$ Furthermore, the

\footnotetext{
${ }^{51}$ See UNFCCC (2020b).

${ }^{52}$ See United Nations (2019).

${ }^{53}$ See United Nations (2019).

${ }^{54}$ Article 2, Section 1 of Paris Agreement (2015).

${ }^{55}$ Article 5 of Paris Agreement (2015). Carbon sinks remove greenhouse gases from the air by a process, activity, or mechanism. Reservoirs are any place carbon is stored within the carbon cycle, such as the ocean, limestone, coal, oil, and the atmosphere. See IPCC (2014) at 127; National Oceanic and Atmospheric Administration (2019).
} 
agreement encourages parties to engage in 'voluntary cooperation' through the use of 'internationally transferred mitigation outcomes' (carbon market mechanisms). ${ }^{56}$

Even though the Paris Agreement is still very understanding of the inability of developing countries to reduce emissions without additional (technical or financial) assistance, all parties (including developing countries) are expected to honour their commitments made in their respective NDC's. Therefore, Article 9 of the agreement encourages developed countries to provide financial resources to developing countries, either through voluntary contributions or through the three financial mechanisms available: the Financial Mechanism of the Convention, the Adaptation Fund from the Kyoto Protocol, and the Green Climate Fund. ${ }^{57}$ Furthermore, to better facilitate mitigation and adaptation on the part of developing countries, the agreement encouraged 'technology development and transfer' through a Technology Framework. ${ }^{58}$ Finally, the agreement expects cooperation on the part of all parties, to 'enhance the capacity of developing country Parties,' in order to implement the goals of the Paris Agreement in a sustainable way. ${ }^{59}$

Overall, the Paris Agreement revolves around "nationally determined contributions" (NDCs), which require national governments to create, maintain, and communicate plans to lower greenhouse gas emissions according to both the agreement goals and their national priorities. ${ }^{60}$ Therefore, parties must report on their efforts to reduce carbon emissions (with NDC's every five years, officially starting in 2020), submit Biennial Transparency Reports (BTRs) on national levels of greenhouse gases and the 'information necessary to track progress in implementing and achieving' their NDC's (starting in 2024), and participate in a Global Stocktake process where global progress will be accessed every five years (starting in 2023). ${ }^{61}$

This focus and commitment on information gathering, sharing, and reporting is the greatest innovation of the Paris Agreement. For the first time under the UNFCCC, public awareness, education, and access to information were included. ${ }^{62}$ The Paris Agreement provides a requirement for countries to be transparent and clear in their commitments and actions, while still allowing flexibility for the

\footnotetext{
${ }^{56}$ Article 6 of Paris Agreement (2015).

${ }^{57}$ The Financial Mechanism of the Convention is the Global Environment Facility (GEF), which is an independent international financial institution with goals that align to the Paris Agreement, except that only parts of their funds are allocated toward climate change mitigation. It receives funding from its member states and works with its partners to assist developing countries. See Lattanzio (2015). The Adaptation Fund of the Kyoto Protocol receives funding through its emissions trading mechanisms and elective contributions that go directly to developing countries for assistance in their efforts toward the Paris Agreement. See Leggett (2020). The Green Climate Fund was created by the UNFCCC to organise and direct funds towards developing countries for lowering greenhouse gas emissions and enhancing their mitigation and adaptation efforts (especially for those most vulnerable to the effects of climate change). The funds are supplied by developed countries and any other state or government body that have the ability to contribute. See Green Climate Fund (2020).

${ }^{58}$ Article 10 of Paris Agreement (2015).

${ }^{59}$ Article 11 of Paris Agreement (2015).

${ }^{60}$ See Fuertes \& Harries (2019) at 11.

${ }^{61}$ See UNFCCC (2019b).

${ }^{62}$ Article 12 of Paris Agreement (2015).
} 
differing capacities of the parties. Therefore, in order to improve upon previous international emissions reduction endeavours, the Paris Agreement established an 'enhanced transparency framework' complete with a peer-review compliance mechanism. ${ }^{63}$

However, it was not until COP24 in Katowice, Poland, in December 2018, that the parties agreed to many of the guidelines and processes for reporting and transparency. ${ }^{64}$ The 'Katowice Package' clarified some ambiguities of the Paris Agreement, by adopting the Enhanced Transparency Framework (ETF), which provides guidelines for parties to report their NDC's. ${ }^{65}$ The ETF is a tool to monitor progress and includes an expert review process in which the comprehensive reports of parties are reviewed for consistency with their NDC and the goals of the Paris Agreement. By promoting greater environmental transparency, integrity and robust accounting in relation to international cooperation, nations can greatly improve results in the fight against climate change. ${ }^{66}$

In particular, the ETF requires reporting greenhouse gas emissions and NDC progress tracking, technical reviews of the reports by independent Technical Expert Review Teams for advisement purposes, and multilateral facilitative consideration (transparency to the international community for the purpose of accountability and sharing best practices). ${ }^{67}$ The ETF also includes a 'transparency rulebook' (called 'Transparency MPGs - Modalities, Procedures, and Guidelines”), which along with the BTRs will go into force in $2024{ }^{68}$

The lesson from Kyoto was that one cannot compel sovereign nations to act without their consent. Inevitably, mandatory carbon emissions requirements were set at levels that could be easily achieved, leading to 'weak action' on the part of national governments, which allowed them to be 'compliant' nonetheless. Moving forward, a more important goal is accurate and honest action on the part of nations, even if it is not ideal. On the other hand, an indirect expectation of the Paris Agreement was to get the largest carbon emitters (China, US, EU, India, Russia, Japan) to commit to action, and therefore set an example for all other nations (and for each other).

\section{Comparing the Kyoto Protocol and Paris Agreement}

The process of reducing greenhouse gas emissions is complex and difficult, requiring transitioning economies which rely heavily on carbon to more carbonfree sources. Therefore, international environmental agreements could possibly be more successful if they provide guidelines for policies and include more definitive projected outcomes. While the Kyoto Protocol set specific targets for carbon emission reductions, and the Paris Agreement required states to set their own

\footnotetext{
${ }^{63}$ Article 13 of Paris Agreement (2015).

${ }^{64}$ See Fuertes \& Harries (2019).

${ }^{65}$ See Hanle, Gillenwater, Pulles \& Radunsky (2019).

${ }^{66}$ Article 6, Section 2 of Paris Agreement (2015).

${ }^{67}$ See May (2019).

${ }^{68}$ Fuertes \& Harries (2019) at 18-21.
} 
specific targets based on their national abilities, the responsibility on how these targets will be met fell on the states in both instances. Neither agreement reached nor is projected to reach its goals in their respective time frames, which is problematic due to the worsening effects of climate change as the concentration of greenhouse gases in the atmosphere continues to rise.

While the Kyoto Protocol established legally binding emissions reduction targets with penalties for noncompliance, it only applied to developed nations (thus excluding developing nations who were becoming major contributors of global emissions and who were in the process of industrialisation). Since the Kyoto Protocol only applied to developed countries, who were historical polluters, it was seen as unfair because of its exclusion of newly industrialised nations like China, currently the largest carbon emissions contributor.

On the other hand, the Paris Agreement differs in that all countries were required to create NDCs to lower emissions. The NDC requirement of the Paris Agreement allows it to be fairer, as it applies to all nations without making hard targets. Because the Paris Agreement has no language that forces parties to make unfeasible commitments, it is considered more flexible than the Kyoto Protocol. However, this also means that the Paris Agreement has no penalties for noncompliance so that developing countries which could not reach their targets are not discouraged from attempting to do so by ratifying the text anyway. Where the Paris Agreement encourages compliance is in its requirements for monitoring, reporting, and regular reassessment of targets with a goal of moving towards the agreement's broader objectives of keeping temperature change below $2{ }^{\circ} \mathrm{C} .{ }^{69}$

Unfortunately, progress by the Paris Agreement in keeping the temperature change below $2^{\circ} \mathrm{C}$ has been determined insufficient by recent studies. ${ }^{70}$ If major emitters keep their current commitments, global warming is estimated to reach between 2.7 and $3.7^{\circ} \mathrm{C}$ by the end of this century, which would have massive negative effects on the world's ecosystems and human life. ${ }^{71}$ Reports prior to 2020 by the UN show that there is no sign of emissions peaking in the near future as they continue to steadily increase. ${ }^{72}$ Scholars are also sceptical of the long term viability of the Paris Agreement, siting concerns that it is not binding and therefore there is no guarantee that parties will both honour their NDC commitments and keep 'ratcheting up' their efforts. There is also doubt whether the 'peer-pressure' from the 'pledge-and-review' component of the Global Stocktake process will work. $^{73}$ Nonetheless, the Paris Agreement is not static and like the whole UNFCCC process is designed to adapt and evolve over time.

\footnotetext{
${ }^{69}$ Article 2, Section 1a of Paris Agreement (2015).

${ }^{70}$ Peters, Andrew, Canadell et al. (2017) at 118-122; See Kuramochi, Fekete, Luna et al. (2018).

${ }^{71}$ See Denchak (2018).

${ }^{72}$ See Hook (2019c).

${ }^{73}$ Sachs (2019) at 865.
} 


\section{Implementation of the Paris Agreement by the EU and China}

Currently, the Paris Agreement is what is driving the UNFCCC effort to combat climate change at a global scale. Although the US was one of the original signatories, the Trump administration announced in 2017 that it would withdraw, despite the US being one of the biggest greenhouse gas emitters. President Trump claimed that implementing the existing US NDC would negatively affect the economy and therefore make the country less competitive against China and the EU. China and the EU however, ratified the agreement and plan to adhere to their commitments.

China, the US, and the EU are the three largest greenhouse gas emitters, respectively. In 2018, China accounted for $29.7 \%$ of emissions, the US $13.9 \%$, and the EU 9.1\%. ${ }^{74}$ They also lead in cumulative emissions since 1750 . The US has produced $25 \%$ of total emissions, the EU about $22 \%$, and China $13 \%{ }^{75}$ Since these nations have contributed the most greenhouse gases, and continue to do so, their actions regarding the Paris Agreement are imperative. ${ }^{76}$ Of course, it's worth noting that carbon emissions numbers look different from a per-capita accounting. Per capita emissions are much larger in industrial countries like Canada, Australia and the US, as well as wealthy kingdoms of the Arabian Peninsula. ${ }^{77}$

All parties to the UNFCCC submitted 'Intended Nationally Determined Contributions' (INDC's) for the COP21 in Paris (before or after the conference). The Paris Agreement requires that parties submit their NDC's by 2020, therefore almost all of the submitted INDC's become NDC's. ${ }^{78}$ Consequently, the first official NDC's are due in 2020. They could be identical to the existing ones, updated in some way, or 'enhanced' (further pledges on greenhouse gas emission mitigation). ${ }^{79}$ Overall, what is most important currently is that the parties continue to report under the Paris Agreement requirements and expectations to keep better track of their progress on the dangers and the reduction of global carbon emissions.

While the world awaits the official NDC reports due in 2020, several nongovernment organisations do collect and analyse information on the progress of government climate action and the commitments of each Party to the Paris Agreement. ${ }^{80}$ Independent scientific analyses can show the sufficiency of legislation

\footnotetext{
${ }^{74}$ Crippa, Orregionni, Guizzardi et al. (2019) at 9; See Levin \& Lebling (2020).

${ }^{75}$ See Center for Climate and Energy Solutions (2020).

${ }^{76}$ Furthermore, according to a recent EU report: "In 2018, China, the United States, India, the EU28, Russia and Japan - the world's largest CO2 emitters - together accounted for $51 \%$ of the population, $65 \%$ of global Gross Domestic Product, $80 \%$ of total global fossil fuel consumption and emitted $67.5 \%$ of total global fossil CO2." Crippa, Orregionni, Guizzardi et al. (2019) at 9, but by numbers the order should be China, US, EU28, India, Russia, Japan.

${ }^{77}$ In particular, Saudi Arabia, Australia, and Canada have higher per capita carbon emitters than the US. For a list of the top per-capita carbon emitters see: Union of Concerned Scientists (2020).

${ }^{78}$ Fuertes \& Harries (2019) at 13.

${ }^{79}$ See Fransen, Mogelgaard, Northrop \& Levin (2017).

${ }^{80}$ Some of these organisations include: Climate Action Tracker (https://climateactiontracker.org/), the International Carbon Action Partnership (https://icapcarbonaction.com/en/), the Global Carbon Project (https://www.globalcarbonproject.org/), and the Climate \& Development Knowledge Network (https://cdkn.org/?loclang=en_gb)
} 
based on projections. In general, national government action is considered insufficient if their NDC and legislation do not lead to substantial collective emissions reductions to keep global temperature rise below $2^{\circ} \mathrm{C}$, the goal of the Paris Agreement.

In the absence of the US from the Paris Agreement, the actions of China and the EU seem to matter the most in the fight to reduce global carbon emissions and lower rising temperatures. Because China accounts for almost 30\% of current carbon emissions, their actions and their example are of paramount importance. The EU on the other hand, stands as the largest emitter from all the industrialised nations of the world. The Europeans most certainly have a legacy obligation to be responsible and it appears that they are taking the right steps.

\section{China's Nationally Determined Contributions and Implementation of Commit- ments}

China submitted its first NDC to the UNFCCC in 2015, which included many categories but broadly covered energy, industrial systems, construction and transportation, carbon sinks and a variety of capacity building initiatives. ${ }^{81}$ Overall, the Chinese government committed to peak carbon emissions in 2030 and decreasing emissions per unit of GDP by $60-65 \%$ from 2005 levels by the same year. ${ }^{82}$ They also plan to increase the share of non-fossil fuel sources of energy consumption to $20 \%$, and increase forest stock volume by 4.5 billion cubic meters from the 2005 level. $^{83}$

To implement these goals, China's 2015 NDC plan included policies in "regime building, production mode and consumption pattern, economic policy, science and technology innovation and international cooperation." ${ }^{84}$ China's plans strengthen regulations to reflect climate objectives and create regionalised, differentiated targets. They will expand renewable energy development and develop a circular economy through recycling. Low-carbon energy will be promoted in the agriculture, service, transportation, and building industries. ${ }^{85}$ They also plan to increase carbon sinks through afforestation, educate citizens, optimise water sources for climate resilience, and fund science and technology research. ${ }^{86}$ Overall, China's NDC is thorough and wide-ranging from governmental to individual action, which should promote reducing greenhouse gas emissions. ${ }^{87}$

\footnotetext{
${ }^{81}$ China's NDC also showed how some of their climate related goals had already been achieved, and their emissions per unit of GDP were $33.8 \%$ lower than in 2005. Additionally, non-fossil fuels make up $11.2 \%$ of energy consumption, forested area was increased 21.6 million hectares, and installed capacity of hydro power, on-grid wind power, and solar power increased by $2.57,90$, and 400 times, from 2005 levels. PRC Department of Climate Change (2015) at 3.

${ }^{82}$ Denchak (2018).

${ }^{83}$ PRC Department of Climate Change (2015) at 5.

${ }^{84}$ PRC Department of Climate Change (2015) at 5.

${ }^{85}$ PRC Department of Climate Change (2015) at 8-9.

${ }^{86}$ PRC Department of Climate Change (2015) at 11.

${ }^{87}$ For more information on Chinas continuing efforts to address its Paris Agreement commitments, see Ministry of Ecology and Environment of the People's Republic of China (2019).
} 
China's greenhouse gas emissions are primarily due to coal. China uses more coal then the rest of the world combined, accounting for $50.5 \%$ of world coal consumption in $2018 .{ }^{88}$ China's uses coal for both energy production and for heating, and its low cost has greatly contributed to its economic growth. However, coal is a major contributor to climate change, and in 2018 roughly $20 \%$ of global carbon emissions were from Chinese combustion of coal. ${ }^{89}$

Between 2013 and 2016, when China submitted its NDC, carbon emissions were steady. According to the Columbia University Centre on Global Energy Policy that was due to a variety of reasons, including structural shifts, cyclical market downturn, and slower economic growth. ${ }^{90}$ Another great contributor to the stabilisation of China's carbon emissions during that period, was the increased use of renewable energy, due to large subsidies by the government.

Although China is the world's largest fossil fuel burner, it's also the world's largest renewable energy user. China leads the word in renewable energy capacity, and in 2018 it accounted for $43 \%$ of the renewable energy capacity added globally. ${ }^{91}$ Renewable energy sources (hydropower, wind, and solar) have grown significantly this decade, providing $26 \%$ of all electricity generated in China in 2018. ${ }^{92}$ Finally, China had the largest market in electric vehicles (EVs), as there were 2.3 million on the roads in $2018 .^{93}$ Part of their efforts to adhere to their NDC includes regulation and financial incentives toward the improvement of motor vehicle efficiency. ${ }^{94}$

However, in the past couple of years, the Chinese government has reversed on some of the policies that contributed to the stabilisation of its carbon emission. In particular, the government suspended its subsidies on solar and wind projects in 2018 and 2019, lifted a previous ban on new coal-fired power plant construction and authorised the construction of new coal power capacity, terminated subsidies for electric vehicles (in 2020), and delayed the full implementation of the national carbon trading scheme to 2021 (which was expected to launch in July 2017). ${ }^{95}$ Loss of government subsidies in the last two years for solar and wind projects has led to dramatic decline in investment in renewable energy. ${ }^{96}$ Despite China's better efforts to decrease carbon emissions, new coal fired plants are still being built. ${ }^{97}$ This is most likely due to the demand for coal that is still required for such a large developing country, as there are simultaneous goals of increasing GDP and alleviating poverty. ${ }^{98}$

China is currently in the transition process to a national carbon emissions trading market for their power-generation sector, which will cover $40 \%$ of their

\footnotetext{
${ }^{88}$ Sandalow (2019) at 57.

${ }^{89}$ Sandalow (2019) at 57.

${ }^{90}$ Sandalow (2019) at 17.

${ }^{91}$ Sandalow (2019) at 66.

${ }^{92}$ Sandalow (2019) at 66.

${ }^{93}$ See China Power Team (2020).

${ }^{94}$ See Leggett (2015).

${ }^{95}$ See Climate Action Tracker (2019a).

${ }^{96}$ See Hook (2019b).

${ }^{97}$ See Hook (2019a).

${ }^{98}$ Xiaoguang (2017) at 3.
} 
total emissions. ${ }^{99}$ Once fully implemented, it will almost double the global carbon emissions trading market. The Chinese carbon trading market, that was supposed to launch nationally in July 2017, has only been operating in eight pilot regions, and is now not expected to be nationally implemented until $2021 .{ }^{100}$

Finally, China is also financing projects abroad that will increase greenhouse gas emissions. China's "Belt and Road Initiative" (BRI) has funded billions of dollars' worth of foreign oil and coal projects since 2000, but the government is now being pressured to switch that funding to green initiatives to help with overall climate commitments. ${ }^{101}$ They currently back 60 overseas projects that are facing economic difficulties from the Covid-19 recession, and environmentalists are strongly suggesting that the Chinese government not provide them further support. ${ }^{102}$ It would benefit China greatly to reallocate the funds for the coal-fired power plants and palm oil plantations to renewable sources of energy instead, since they will become cheaper in the long run. China's decision on this matter will impact several developing countries efforts to reduce their carbon emissions, and greatly affect the world's ability to meet international carbon emissions reduction goals. ${ }^{103}$

Based on projections of current policy initiatives, China is expected to reach its NDC targets. Greenhouse gas emissions are expected to peak around 2030 but rise steadily from now until then (which will make the needed decline that much steeper). Renewable energy sources are expected to reach $23 \%$ to $29 \%$ share of total primary energy consumption by 2030, and carbon intensity of its GDP is to be reduced by $68 \%$ compared to 2005 levels. ${ }^{104}$ However, according to the Climate Action Tracker, China's rating is "highly insufficient," which means that even if fully implemented, these goals are insufficient in holding global warming below $2^{\circ} \mathrm{C}$. That means that the 'Initial NDC' was not ambitious enough, and therefore China will have to submit an 'enhanced NDC' in 2020.

Overall, China laid out a detailed account of the plans to implement actions to meet the goals of the Paris Agreement and showed potential to follow through with a national carbon market and regulations with incentives to decrease emissions in multiple sectors. However, big issues remain, such as the recent reduction in government subsidies for renewable energy, increase in the use of coal again, and the implications of BRI domestically.

\section{EU's Nationally Determined Contributions and Implementation of Commitments}

The member-countries of the EU jointly submitted their first NDC in March of 2015, and they committed to collectively reduce greenhouse gas emissions $40 \%$ by the year 2030 compared to 1990 levels. ${ }^{105}$ Their NDC covers the sectors of energy, industrial processes and product use, agriculture, waste, and land use and

\footnotetext{
${ }^{99}$ See Baker (2019).

${ }^{100}$ See Temple-West (2020).

${ }^{101}$ See Sheperd (2020).

${ }^{102}$ See Sheperd (2020).

${ }^{103}$ See Sheperd (2020).

${ }^{104}$ See Climate Action Tracker (2019a).

${ }^{105}$ See European Union (2015).
} 
forestry (LULUCF), with many specific subcategories. ${ }^{106}$ The EU's NDC, though short on details, made it clear that they plan to reduce all types of greenhouse gases, and enhance their carbon capture efforts, by creating new laws and regulations before 2020. ${ }^{107}$ However, unlike China, the EU was able to peak its greenhouse gas emissions by 1979 , and has been steadily reducing its output since then, but at low rates each year.

The EU already has legislation in place to meet its NDC commitments, most of which was updated recently. Between May 2018 and May 2019, the EU adopted its new energy rulebook, called the "Clean Energy for all Europeans." This is a comprehensive package that includes eight legislative acts, covering a wide range of efforts to transition away from fossil fuels and towards cleaner energy. In particular, it includes a directive on Renewable Energy mandating the increase in use of eclectic power for transportation vehicles, a directive on Energy Performance in Buildings mandating the decarbonisation of existing building stock, and a regulation on the role of land use and forestry in emissions reduction. ${ }^{108}$ The main one is the EU Regulation on the Governance of the Energy Union and Climate Action, which applies the Paris Agreement framework domestically, and consolidates all past 'climate change' related governance regulations. ${ }^{109}$

The EU is on track to reduce emissions at least $40 \%$, if not almost $48 \%$ by $2030 .{ }^{110}$ Even though plans for coal phase outs by EU member states mean that $43 \%$ of installed coal power will still be in use by 2030, the 2018 EU Renewable Energy Directive committed to a goal of $14 \%$ share of renewables for the EU in the transport sector by $2030 .{ }^{111}$ Finally, overall natural gas consumption in the EU is decreasing, despite some member states attempting to develop natural gas infrastructure. The European Investment Bank stopped funding investment in this infrastructure, preventing natural gas development and working towards the Paris Agreement goals.

Perhaps one of the greatest successes of the EU so far in fighting climate change is its Emissions Trading System (ETS). Launched in 2005, it covers 31 countries, it's a cap-and-trade carbon market that limits emissions from over 11,000 energy-intensive installations and companies and covers over $45 \%$ of the EU's greenhouse gas emissions. ${ }^{112}$ According the EU Commission, the ETS is on track to lower emissions from covered sectors by $21 \%$ (2005 levels) by 2020 . By some estimates, the value of the global carbon market in 2018 was \$164 billion, with the EU ETS accounting for about $90 \%$ of that. ${ }^{113}$

Despite all that, the EU also has an insufficient rating from the Climate Action Tracker scale, meaning again that although they are meeting their goals, that is still not enough to keep global temperatures from rising above $2^{\circ} \mathrm{C}$. The EU had

\footnotetext{
${ }^{106}$ See European Union (2015).

${ }^{107}$ See European Union (2015).

${ }^{108}$ See Climate Action Tracker (2019b); Kezee, Archick \& Leggett (2020); European Commission (2020c)

${ }^{109}$ See European Union (2018)

${ }^{110}$ See Climate Action Tracker (2019b).

${ }^{111}$ See Climate Action Tracker (2019b); European Commission (2020c)

${ }^{112}$ See European Commission (2020a)

${ }^{113}$ See Twidala (2019).
} 
ambitious goals of reducing emissions by $40 \%$ of 1990 levels by 2030 , but the governmental bodies of the EU are working towards increasing it to a 55\% reduction, which is expected to be committed to in a new NDC for $2020 .^{114}$ Criticism of the NDC for the EU is that they could easily reach $48 \%$ by 2030 if they improve their already adopted policies and take action that is congruent with their level of economic development. ${ }^{115}$

Finally, in April 2020, the EU Commission submitted for comments its proposed new regulation (European Climate Law) to achieve 'climate neutrality by $2050 .{ }^{116}$ This 'European Green Deal' is the most ambitious European effort yet, promising to completely transform the EU market and society over the next 30 years. If adopted, it could cost the EU between €4.6-5.0 trillion over the next 30 years, in order to transform such industries like agriculture and transportation to zero carbon emitters. ${ }^{117}$ The 'European Green Deal' also includes strategy for adaptation and transitioning to circular economies. ${ }^{118}$ This proposed legislation is moving in the right direction, as it is full of ambition that correlates with the Paris Agreement. It prioritises both the economy and wealth of the member states and the health of the planet, which makes it a good example to follow. ${ }^{119}$

Overall, although the EU's NDC is less thorough than that of China, EU laws supporting the goals of the NDC are already in place and being improved upon. The new 'European Green Deal' to be carbon-neutral by 2050, could however face real challenges, as some member-states rely heavily on coal and might require even more funding than proposed to decarbonise their economies. ${ }^{120}$ Although the EU is not increasing its emissions and continues to be an example for reducing them, the success of its lofty goals remains to be seen.

\section{Conclusion (Post Covid-19 Implications for Climate Change)}

Climate change is one of the most pressing issues of our times, with a growing effect on the natural environment and human life. While the science behind the issue has been highly debated, research shows with extremely high certainty that man-made activities have been both responsible for the rise in global temperatures, and that there will be major consequences to the ecosystem and human life for not reducing carbon emissions. Therefore, international efforts to deal with climate change began with the UNFCCC, and continued through the subsequent Kyoto Protocol and the Paris Agreement, which provided the most comprehensive action plans for reducing emissions.

\footnotetext{
${ }^{114}$ See Climate Action Tracker (2019b).

${ }^{115}$ See Climate Action Tracker (2019b).

${ }^{116}$ See European Commission (2020b).

${ }^{117}$ See Mathiesen (2020).

${ }^{118} \mathrm{~A}$ large amount of funding is set aside for the Just Transition Mechanism for those dependent on carbon-intensive economies. Also included are plans for a "carbon border adjustment mechanism" to reduce competitiveness between members and prevent shifting emissions from one member-state to another, to keep the EU united in this matter. See Kezee, Archick \& Leggett (2020).

${ }^{119}$ See The Economist (2019).

${ }^{120}$ See Kezee, Archick \& Leggett (2020).
} 
The Kyoto Protocol set binding targets with consequences for noncompliance in terms of carbon emissions - a type of "command and control" approach to dealing with carbon emissions. However, its applicability to only developed countries, and its exclusion of the largest carbon emitters (like the US and China), doomed the Kyoto Protocol from the start. The lesson for the global community was to let each country pursue its own policies and efforts in reducing its own carbon emissions, with goals to meet UNFCCC targets.

The Paris agreement on the other hand asks each country to do "whatever they can" - as long as they report it and actually try to do what they say. The implication being that the 'safe operating space' is shrinking fast, and therefore we need to know precisely what is the current levels of greenhouse gas emission in the atmosphere, where are they coming from, how fast are they growing (or not), and precisely what actions are taken by national governments to reduce their carbon emissions. The more the global community knows, the better/faster we can all respond/adopt to dramatic climate changes to come.

Unfortunately, the very nature of international law, which requires consensus and lacks the capacity to compel action on the part of sovereign nations, dictates that the best we can get right now in terms of dealing with climate change is a nonbinding 'Paris Agreement' type of action. Reporting through NDC's and reviewing of national implementation might be our last best hope for achieving meaningful reduction in carbon emissions.

As of 2019, what we have seen in terms of actions, at least from China and the EU, has been insufficient: in curbing the growth of greenhouse gas emissions and peaking carbon emissions, or in reducing the rising in global temperatures. Based on the Paris Agreement, 2020 was going to be the year when parties where expected to either submit their official NDC's or submit 'enhanced NDC's.' The annually scheduled COP in Glasgow, Scotland, in November 2020 would have tested the long-term viability of the Paris Agreement. ${ }^{121}$ Unfortunately, Mother Nature had different plans.

The global pandemic that has infected millions of people, killed hundreds of thousands, and completely disrupted the global economy, has also led to a significant reduction in carbon emissions in 2020 (as a result of the near global lockdown imposed by national governments in combating the spread of the corona virus). ${ }^{122}$ As a result of the Covid-19 global lockdown, by April 2020, daily emissions had on average decreased by $17 \%$ compared to the 2019 mean, almost half of which was due to decreased surface transport. ${ }^{123}$ Projections for 2020 (depending on the lockdown extend) range from $4 \%$ to $7 \%$ reduction in carbon emissions. ${ }^{124}$ For the first time in post industrialised human history, we have an actual live case of what life would be like without excessive use of energy (for transportation, production, and consumption).

The Covid-19 pandemic can have several implications for the Paris Agreement and climate change. First, 2020 NDC reporting deadlines might not be honoured,

\footnotetext{
${ }^{121}$ COP26 was postponed to October 2021, due to Covid-19.

${ }^{122}$ Le Quéré, Jackson, Jones et al. (2020) at 1.

${ }^{123}$ Le Quéré, Jackson, Jones et al. (2020) at 1.

${ }^{124}$ Le Quéré, Jackson, Jones et al. (2020) at 1.
} 
understandably. Second, dealing with Covid19 could push climate change commitments from the forefront of national policy priorities. Finally, just like in the case with of the 'European Green Deal', fighting climate change could become a means for alleviating the economic recession caused by Covid-19.

The ultimate result of Covid-19 on developed societies, where social distancing has led to dramatic drops in energy consumption (which emits carbons), while at the same time has not led to the total collapse of western civilisation, can be a new impetus for global action to combat climate change. Therefore, the implication of the Covid-19 pandemic is that there is an opening for parties to update and/or reconsider their NDC, even if they do not have to submit new ones.

This is the perfect time for national governments to both craft a post Covid-19 action plan on how to reduce their carbon emissions (along with other polices that combat climate change), and communicate such plans to the rest of the world (for 'review' and evaluation/emulation). ${ }^{125}$ National governments are expected to submit their second NDC's by the end of 2020, thus presenting an opportunity for a new and more in depth look into ways to deal with climate change. If we all know what we are all planning to do and what impact it will have, it should help the global community to properly respond to the most pressing issue of our times.

\section{References}

Baker, J. (2019). 'All Eyes on China as National Carbon Market Plan Emerges from Haze.' in Ethical Corporation (Sept. 1, 2019). http://www.ethicalcorp.com/all-eyes-china-na tional-carbon-market-plan-emerges-haze

Bauer, E., Claussen, M., Brovkin, V. \& A. Huenerbein. (2003) 'Assessing Climate Forcings of the Earth System for the Past Millennium.' In Geophysical Research Letters 30(6). https://doi.org/10.1029/2002gl016639

Björnberg, K.E., Karlsson, M., Gilek, M. \& S.O. Hansson (2017). 'Climate and Environmental Science Denial: A Review of the Scientific Literature Published in 1990-2015' in Journal of Cleaner Production 167:229-41. https://doi.org/10.1016/j. jclepro.2017.08.066

Boer, G. J., McFarlane, N.A. \& M. Lazare (1992) 'Greenhouse Gas-Induced Climate Change Simulated with the CCC Second-Generation General Circulation Model' in Journal of Climate 5(10):1045-77. https://doi.org/10.1175/1520-0442(1992)005 <10 45: ggccsw>2.0.co;2

British Petroleum (BP) (2019) 'BP Statistical Review' BP (Jun. 2019). https://www.bp.co $\mathrm{m} /$ content/dam/bp/business-sites/en/global/corporate/pdfs/energy-economics/statisti cal-review/bp-stats-review-2019-china-insights.pdf

Brown Weiss, E. (2011). 'The Evolution of International Environmental Law.' In Japanese Yearbook of International Law 54:1-27.

Center for Climate Change and Energy Solutions (2020) 'Global Emissions.' Center for Climate and Energy Solutions, (Jan. 7, 2020). https://www.c2es.org/content/internati onal-emissions/.

\footnotetext{
${ }^{125}$ Already, both the US and the EU are considering how to re-build their Covid-19 damaged economies, through 'green - emissions reduction' friendly legislation.
} 
China Power Team (2020) 'How Is China Managing Its Greenhouse Gas Emissions?' China Power (Feb. 11, 2020). https://chinapower.csis.org/china-greenhouse-gas-emis sions/.

Climate Action Tracker (2019a) 'China.' (Dec. 2, 2019). https://climateactiontracker.org/ countries/china/.

Climate Action Tracker (2019b) 'EU' (Dec. 2, 2019). https://climateactiontracker.org/cou ntries/eu/.

Council of the European Union (2019) 'The 2030 Climate and Energy Framework.' Consilium. Council of the European Union, (Dec. 6, 2019). https://www.consilium.eu ropa.eu/en/policies/climate-change/2030-climate-and-energy-framework/\#: :text $=$ The European Council will continue, the end of February 2015.

Crippa, M., Orregionni, G., Guizzardi, D., Muntean, M., Schaaf, E., Lo Vullo, E., Solazzo, E., Monforti-Ferrario, F., Olivier, J. \& E. Vignati (2019). Fossil CO2 and GHG emissions of all world countries. Publications Office of the European Union, Luxembourg. https://ec.europa.eu/jrc/en/publication/eur-scientific-and-technical-research-re ports/fossil-co2-and-ghg-emissions-all-world-countries-0.

Denchak, M. (2018) 'Paris Climate Agreement: Everything You Need to Know.' NRDC, (Dec. 12, 2018). https://www.nrdc.org/stories/paris-climate-agreement-everythingyou-need-know\#sec-summary.

Doha Amendment to the Kyoto Protocol (2012). Proceedings of UNFCCC. https://unf ccc.int/files/kyoto_protocol/application/pdf/kp_doha_amendment_english.pdf.

Dunlap, R. E. (2013) 'Climate Change Skepticism and Denial: An Introduction' in American Behavioral Scientist 57(6):691-98. https://doi.org/10.1177/000276421347 7097.

European Commission (2017) 'Progress Made in Cutting Emissions.' Climate Action European Commission (Feb. 16, 2017). https://ec.europa.eu/clima/policies/strategies/ progress_en.

European Commission (2020a) 'Report from the Commission to the European Parliament and the Council of 16 January 2020' (Jan. 16, 2020). https://eur-lex.europa.eu/legalcontent/EN/TXT/PDF/?uri=CELEX:52019DC0557R(01)\&from=EN

European Commission (2020b) 'Proposal for a Regulation of the European Parliament and of the Council of 04 March 2020.' (Mar. 04, 2020) https://eur-lex.europa.eu/legalcontent/EN/TXT/PDF/?uri=CELEX:52020PC0080\&from=EN

European Commission (2020c) 'Clean energy for all European package' (Accessed Jul. 12, 2020). https://ec.europa.eu/energy/topics/energy-strategy/clean-energy-all-europe ans_en

European Union (2015) 'Intended Nationally Determined Contribution of the EU and its Member States' Submission by Latvia and the European Commission on Behalf of the European Union and Its Member States (Mar. 6, 2015). https://www4.unfccc.Int/ sites/ndcstaging/PublishedDocuments/Sweden\%20First/EU\%20First\%20NDC.pdf

European Union (2018) 'Regulation (EU) 2018/1999 of the European Parliament and of the Council of 11 December 2018' in Official Journal of the European Union (Dec. 21, 2018).

Fransen, T., Mogelgaard K., E. Northrope \& K. Levin (2017). 'Enhancing NDCS by 2020: Achieving the Goals of the Paris Agreement' in World Resources Institute (Nov. 2017). https://files.wri.org/s3fs-public/WRI17_NDC.pdf

Fuertes, O. Z. \& J. Harries (2019). Next Steps under the Paris Agreement and the Katowice Climate Package. Deutsche Gesellschaft für Internationale Zusammenarbeit (GIZ) $\mathrm{GmbH}$, Eschborn. https://www.transparency-partnership.net/ system/files/document/ Next $\% 20$ steps $\% 20$ under $\% 20$ the $\% 20$ Paris\%20Agreement $\% 20$ and $\% 20$ the $\% 20$ Katow ice\%20Climate\%20Package.pdf 
Green Climate Fund (2020) 'About GCF.; Green Climate Fund. (Feb. 12, 2020). https://

Hanle, L. Gillenwater, M., Pulles, T. \& K. Radunsky (2019). Challenges and Proposed Reforms to the UNFCCC Expert Review Process for the Enhanced Transparency Framework. Seattle, WA: Greenhouse Gas Management Institute.

Hook, L. (2019a) 'China ramps up coal power in face of emissions efforts.' Financial Times (Nov. 19, 2019). https://www.ft.com/content/c1feee40-0add-11ea-b2d6-9bf4d $1957 \mathrm{a} 67$

Hook, L. (2019b) 'Climate Change: How China Moved from Leader to Laggard.' Financial Times (Nov. 25, 2019). https://www.ft.com/content/be1250c6-0c4d-11ea-b 2d6-9bf4d1957a67?accessToken=zwAAAW7_GMYgkdO-EIDGDE0R6tOy1pv00 ZV6Zw.MEQCIFaY-bYRI1fFZqC4bYI_OF3LIB_DMFE-vvi6clzzyq3BAiBPCnuQ URcVkQXMS-dCiZ3dW1Su4P-bMkeQEenUTKV6qw\&sharetype=gift?token.

Hook, L. (2019c) 'UN Study Reveals Big Gap in Required Cuts to Emissions.' Financial Times (Nov. 26, 2019). https://www.ft.com/content/30d2692a-0faa-11ea-a225-db2f2 $31 \mathrm{cfeae}$ ?accessToken=zwAAAW7_GI9wkc8w0mkqD6oR6tOiJdsvIxz-rg.MEYCIQ CCfkoDWh8vFnzfM_xS4e99kOKalModezVli_aKbJ2P5AIhAOnSgepfSN_U7W96 SgvCwEphSLyU9L4ZmKKSo7OOsVAx\&sharetype=gift?token=4ee05e72-2e19417f-88b2-3ee7d1fd9c06.

IPCC (2014) 'Climate Change 2014: Synthesis Report. Contribution of Working Groups I, II and III to the Fifth Assessment Report of the Intergovernmental Panel on Climate Change' [Core Writing Team, R.K. Pachauri and L.A. Meyer (eds.)]. IPCC, Geneva, Switzerland.

IPCC (2020) 'History of the IPCC.' IPCC. (Jun. 22, 2020). https://www.ipcc.ch/about/his tory/.

Kezee, P., Archick, K. \& J. A. Leggett (2020). 'EU Climate Action and Implications for the United States' (IF11431; Feb. 14, 2020), U.S. Congressional Research Service. Text in: LexisNexis ${ }^{\circledR}$ Congressional Research Digital Collection. https://fas.org/sgp/ crs/row/IF11431.pdf.

Kuramochi, T., Fekete, H., Luna, L., de Villafranca Casas, M.J., Nascimento, L., Hans, F., Höhne. N. (NewClimate Institute), van Soest, H., den Elzen, M., Esmeijer, K., Roelfsema. M. (PBL Netherlands Environmental Assessment Agency), Forsell, N., Turkovska, O. \& M. Gusti (International Institute for Applied Systems Analysis) (2018). 'Greenhouse gas mitigation scenarios for major emitting countries.' New Climate Institute. https://www.pbl.nl/sites/default/files/downloads/pbl-2018-green house-gas-mitigation-scenarios-for-major-emitting-countries_3127.pdf.

Kyoto Protocol (1997). Proceedings of UNFCCC. New York: United Nations. https://un fccc.int/sites/default/files/resource/docs/cop3/107a01.pdf.

Lattanzio, R.K. (2015). The Global Environment Facility (GEF).' (IF10144; Mar. 9, 2015), U.S. Congressional Research Service. https://www.everycrsreport.com/reports/I F101 44.html

Le Quéré, C., Jackson, R.B., Jones., M.W., Smith, A.J.P., Abernethy, S., Andrew, R.M., De-Gol, A.J., Willis, D.R., Shan, Y. Canadell, J.G., Friedlingstein, P. Crewtzjg, F. \& G.P. Peters (2020) 'Temporary Reduction in Daily Global CO2 Emissions during the COVID-19 Forced Confinement.' in Nature Climate Change 10:647-653. https://doi. org/10.1038/s 41558-020-0797-x.

Le Treut, H., Somerville, R., Cubasch, U., Ding, Y., Mauritzen, C., Mokssit, A., Peterson, T. \& M. Prather (2007). 'Historical Overview of Climate Change' in S. Solomon, D. Qin, M. Manning, Z. Chen, M. Marquis, K.B. Averyt, M. Tignor \& H.L. Miller (eds.) Climate Change 2007: The Physical Science Basis. Contribution of Working Group I to the Fourth Assessment Report of the Intergovernmental Panel on Climate Change. Cambridge University Press, Cambridge, United Kingdom and New York, NY, USA. 
Leggett, J.A. (2015). China's "Intended Nationally Determined Contribution" to Addressing Climate Change in 2020 and Beyond. CRS in Focus, IF10248, Congressional Research Service, [Getzville, New York]: William S. Hein \& Company, [2015] [2018]. Text in: LexisNexis® Congressional Research Digital Collection. https://www.everycrsreport.com/files/20150706_IF10248_58ae8b80e5e 78f9cc60880d3ee5db4c469333484.pdf

Leggett, J.A. (2020). The United Nations Framework Convention on Climate Change, the Kyoto Protocol, and the Paris Agreement: A Summary. R46204; Jan. 29, 2020), U.S. Congressional Research Service. https://www.everycrsreport.com/reports/R46204. html\#_Toc31293264

Levin, K. \& K. Lebling (2020). 'CO2 Emissions Climb to an All-Time High (Again) in 2019: 6 Takeaways from the Latest Climate Data,' in World Resources Institute (May 5, 2020). https://www.wri.org/blog/2019/12/co2-emissions-climb-all-time-high-agai n-2019-6-takeaways-latest-climate-data.

Mathiesen, K. (2020) 'Europe's Climate Goal: Revolution' in Politico (Jun. 17, 2020) https://www.politico.eu/article/europe-climate-goal-revolution-net-zero-emissions/

May, P. (2019). 'Understanding the Enhanced Transparency Framework.' In Climate and Development Knowledge Network (Jun. 18, 2019). https://cdkn.org/2019/06/featureunderstanding-the-enhanced-transparency-framework/?loclang=en_gb.

Ministry of Ecology and Environment of the People's Republic of China (2019) 'China's Policies and Actions for Addressing Climate Change.' http://english.mee.gov.cn/ Resources/Reports/reports/201912/P020191204495763994956.pdf

National Oceanic and Atmospheric Administration (NOAA) (2019) 'Carbon Cycle' NOAA (Feb. 2019). https://www.noaa.gov/education/resource-collections/climate/ carbon-cycle.

Paris Agreement (2015). Proceedings of UNFCCC. New York: United Nations. https://un fccc.int/files/essential_background/convention/application/pdf/english_paris_agreem ent.pdf.

Peters, G.P., Andrew, R.M., Canadell, J.G., Fuss, B., Jackson, R.B., Korsbakken, J.I., Le Quéré, C. \& N. Nakicenovic (2017) 'Key Indicators to Track Current Progress and Future Ambition of the Paris Agreement.' in Nature Climate Change 7(2): 118-22. https://doi.org/10.1038/nclimate3202.

PRC Department of Climate Change (2015) Department of Climate Change, National Development \& Reform Commission of China 'Enhanced Actions on Climate Change: China's Intended Nationally Determined Contributions.' (30 June 2015) https://www4.unfccc.int/sites/ndcstaging/PublishedDocuments/China First/China's First NDC Submission.pdf.

ProCon.org (2020) 'History of Climate Change Debate.; ProCon.org. (Last modified Mar. 31, 2020). https://climatechange.procon.org/history-of-climate-change-debate/.

Protocol.' In Report of the Conference of the Parties on Its Seventh Session, Held at Marrakesh from 29 October to 10 November 2001. Proceedings of UNFCCC. Geneva, Switzerland: United Nations. https://unfccc.int/resource/docs/2015/cop21/ eng/10a01.pdf

Ricke, K.L. \& K. Caldeira (2014) 'Maximum Warming Occurs about One Decade after a Carbon Dioxide Emission.' in Environmental Research Letters 9(12):124002. doi: 10.1088/1748-9326/9/12/124002.

Sachs, N.M. (2019). 'The Paris Agreement in the 2020s: Breakdown or Break up?' in Ecology Law Quarterly 46:865-909. https://ssrn.com/abstract=346 3892.

Sandalow, D. (2019). 'Guide to Chinese Climate Policy 2019' Columbia University SIPA Center on Global Energy Policy (Sept. 2019) https://energypolicy.columbia.edu/sites /default/files/file-uploads/Guide\%20to\%20Chinese\%20Climate\%20Policy_2019.pdf 
Sheperd, C. (2020) 'China's Belt and Road Urged to Take Green Route.' in The Financial Times (5 June, 2020). https://www.ft.com/content/e00426f4-8ead-11ea-af59-5283fc $4 \mathrm{c} 0 \mathrm{cb} 0$.

Shishlov, I., Morel, R. \& V. Bellassen (2016) 'Compliance of the Parties to the Kyoto Protocol in the first commitment period' in Journal of Climate Policy 16(6):768-782. https://doi.org/10.1080/14693062.2016.1164658

Stips, A., Macias, D., Coughlan, C., Garcia-Gorriz, E. \& X. San Liang (2016) 'On the Causal Structure between CO2 and Global Temperature.' Scientific Reports 6:21691. https://doi.org/10.1038/srep21691

Taylor, F. W. (1991) 'The Greenhouse Effect and Climate Change.' in Reports on Progress in Physics 65(1):1. DOI: 10.1088/0034-4885/65/1/201. https://doi.org/ 10.1088/00344885/54/6/002

Temple-West, P. (2020) 'China's Carbon Trading Scheme Struggles to Take Off.' The Financial Times (Jun 5, 2020). https://www.ft.com/content/35a0a860-8eab-11ea-af 59-5283fc4c0cb0?shareType=nongift.

The Economist (2019). 'The EU's Green Deal Is Full of Ambition but Needs More Detail.' The Economist Newspaper (12 Dec., 2019). https://www.economist. com/europe/20 19/12/12/the-eus-green-deal-is-full-of-ambition-but-needs-more-detail

Twidala, S. (2019). 'Value of global CO2 markets hit record 144 billion euros in 2018: report.' Reuters (January 16, 2019). https://www.reuters.com/article/us-global-car bontrading-report/value-of-global-co2-markets-hit-record-144-billion-euros-in-2018report-idUSKCN1PA27H

UN Framework Convention (1992). Proceedings of World Summit on Sustainable Development, Rio de Janeiro. New York: United Nations, General Assembly. https:// unfccc.int/resource/docs/convkp/conveng.pdf.

UNCED (2020) 'United Nations Conference on Environment and Development (UNCED), Earth Summit,' Sustainable Development Goals Knowledge Platform, (Accessed Jun. 22, 2020), https://sustainabledevelopment.un.org/milestones/unced.

UNFCCC (2002) 'Procedures and Mechanisms Relating to Compliance under the Kyoto

UNFCCC (2006) 'Procedures and Mechanisms Relating to Compliance under the Kyoto Protocol.' In Report of the Conference of the Parties Serving as the Meeting of the Parties to the Kyoto Protocol on Its First Session, Held at Montreal from 28 November to 10 December 2005, 93-103. Proceedings of UNFCCC. Geneva: United Nations, 2006. (Accessed Jun. 22, 2020). https://unfccc.int/resource/docs/2005/cmp1 /eng/08a03.pdf\#page $=92$

UNFCCC (2019a) 'What Is the Kyoto Protocol?' UNFCCC. United Nations. (Accessed Dec. 13, 2019). https://unfccc.int/kyoto_protocol.

UNFCCC (2019b) 'What Is the Paris Agreement?' UNFCCC. United Nations. (Accessed Dec. 13, 2019). https://unfccc.int/process-and-meetings/the-paris-agreement/what-isthe-paris-agreement.

UNFCCC (2019c) 'What Is the United Nations Framework Convention on Climate Change?' UNFCCC. United Nations. (Accessed Dec. 12, 2019). https://unfccc.int/pro cess-and-meetings/the-convention/what-is-the-united-nations-framework-convention -on-climate-change.

UNFCCC (2020a) 'Conference of the Parties (COP).' UNFCCC. (Accessed Jun 11, 2020). https://unfccc.int/process/bodies/supreme-bodies/conference-of-the-parties-cop.

UNFCCC (2020b) 'The Doha Amendment.' UNFCCC. United Nations. (Accessed Jun. 22, 2020). https://unfccc.int/process/the-kyoto-protocol/the-doha-amendment

Union of Concerned Scientists (2020) 'Each Country's Share of CO2 Emissions.' Union of Concerned Scientists (May 11, 2020). https://www.ucsusa.org/resources/each-coun trys-share-co2-emissions. 
United Nations (UN) (2019) 'Climate Change.' United Nations. (Accessed Dec. 12, 2019). https://www.un.org/en/sections/issues-depth/climate-change/.

WDED World Commission on Environment and Development (1987) 'Our common future, Brundtland Report.'

Xiaoguang, Z (2017) 'Realizing China's Paris Commitment to Addressing Climate Change: Challenges and Legal Solutions.' In ELR 47(1):10041. 
